JOURNAL OF AWARENESS

$\int_{\substack{\text { ACADEM I } \\ \text { ACADEM }}}^{\text {Cilt:3, Sayl:3, Temmuz 2018 }}$ V-ISSN:2149-6544

http://www.ratingacademy.com.tr/ojs/index.php/joa

JOURNAL OF AWARENES

\title{
OPTIMIZATION OF TURKISH MACRO ECONOMETRIC FISCAL AND MONETARY POLICIES FOR GROWTH
}

\author{
Prof. Dr. Ahmet Mete ÇíLINGİRTüRK \\ Marmara University, Faculty of Economics, Department of Econometrics \\ Istanbul/TURKEY,E-mail: acilingi@marmara.edu.tr \\ Assoc. Prof. Dr. Habib KOÇAK \\ Marmara University, Faculty of Economics, Department of Econometrics \\ Istanbul/TURKEY, E-mail: hkocak@marmara.edu.tr \\ Assist. Prof. Dr. Turgut $\ddot{U} N$ \\ Marmara University, Faculty of Economics, Department of Econometrics \\ Istanbul/TURKEY, E-mail: turgutun@marmara.edu.tr
}

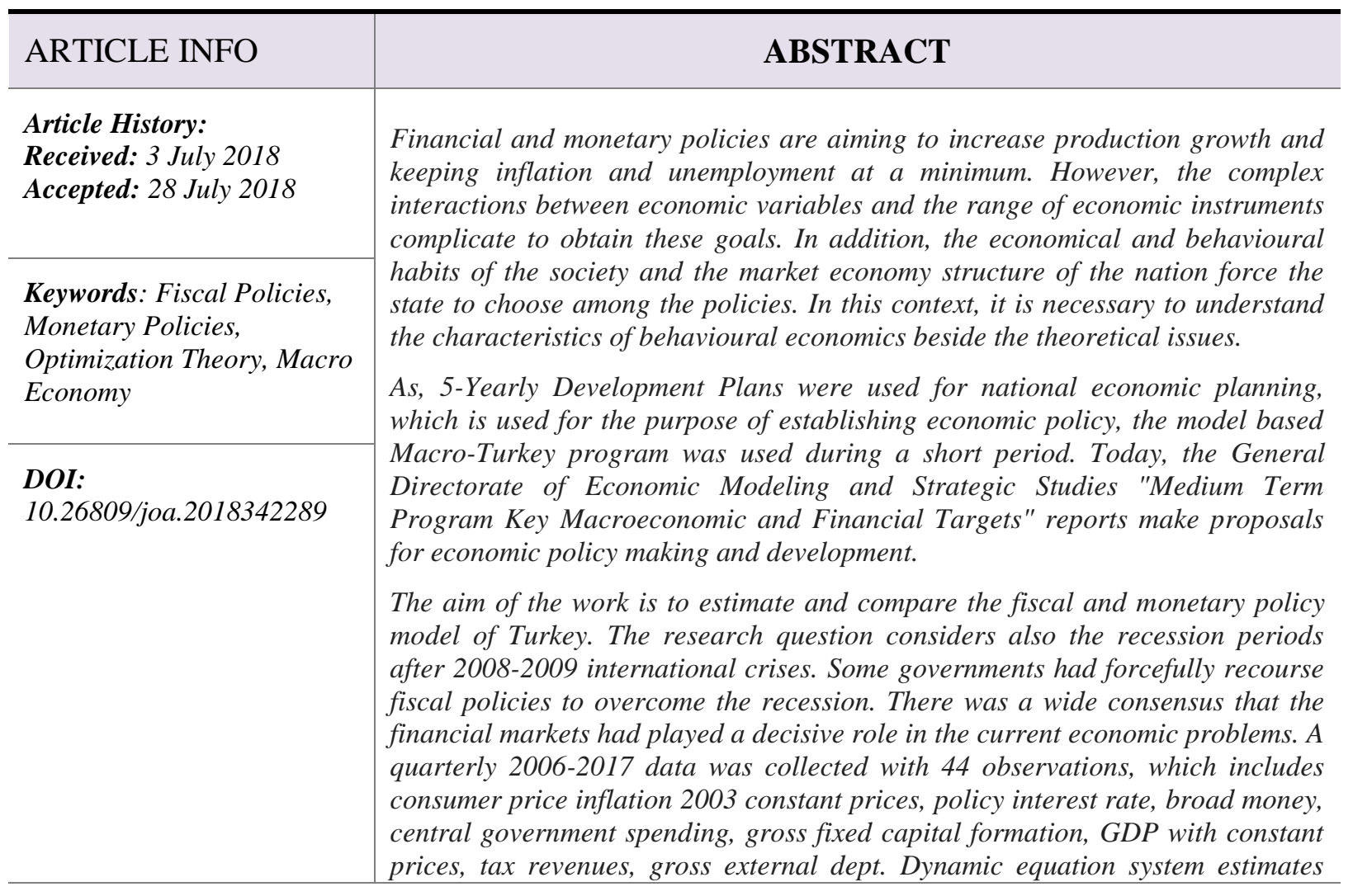


will be held simultaneously with the appropriate variables and indicators. The goal of maximum growth will be optimized under the constraints of Turkish current economic condition. Therefore, the econometric analysis and optimization techniques will be used consecutively.

The macro economical Keynesian coefficients are expected to occur with the model. These coefficients are the main ones used to simulate the dynamic stochastic general equilibrium (DSGE) models used by the central governments to calibrate their policies. The response of the output to fiscal and financial shocks might quantifiable through simulating the model

\section{INTRODUCTION}

Some governments had forcefully recourse fiscal policies to overcome the 2008-2009 recession. There was a wide consensus that the financial markets had played a decisive role in the current economic problems. This crisis has left many governments primarily to make large-scale warning plans. Then they implemented actual consolidation strategies to ensure governments' financial stability. These practices again made current public debates on financial governance important. Monetary authorities are predominantly capable of increasing taxes and / or reducing public spending to keep fiscal balance. At this point, the problem is to decide which types of taxes should be increased and which types of government expenditures should be maintained. Germany, Greece, Portugal, Spain and others decreased public employment, public wages and public investments. On the other side, they carried out consolidation plans with increasing labour wages tax rates and VAT. As a result of these measures, appropriate changes in production, unemployment or international competitiveness will be expected. The economic policy consists of monetary policy, fiscal policy and foreign trade policy. Monetary policy is a component of an economic policy in which instruments such as money supply and interest rates are used by the Central Bank to reach certain economic and monetary targets. Foreign trade policy aimed at achieving the goal of external balance using tariffs and non-tariff instruments. The fiscal policy uses public revenues and expenditures to achieve certain financial, economic, social and political objectives. Economic stability refers to both price stability and full employment. Price stability means that the general level of prices does not increase or decrease very much, in other words it remains constant. Full employment refers to the level at which all production factors in the economy are utilized. For this reason, the state's economic stability means to overcome both inflation and unemployment. Economic growth, on the other hand, is an increase in the national income of the economy. The aims of the fiscal policy are the targets that a government aspires to as a whole. However, some contradictions may arise among these purposes. A government that is fighting inflation for the sake of price stability, has reversed its motive for the purpose of economic growth when it is under pressure to suppress the underlying cause of inflation. Easing the tax burden on capital groups in order to ensure economic growth can adversely affect justice in income distribution by giving a result against low income groups. For this reason, policy makers should not contradict another reason while reaching an aim. This is also the case where it is difficult to implement the fiscal policy. For this reason, policy makers need to be very careful and apply fine-tuning policies by making serious and realistic calculations.

\section{FISCAL AND MONETARY POLICIES}

Public spending is one of the key components of the basic macroeconomic identity. It covers all kinds of expenditures (current, stock and transfer) the government has made. A change in the amount of public expenditure will certainly affect the objectives of the fiscal 
policy. However, when referring to the means of fiscal policy, it is not just the change in the amount of expenditures. At the same time, changes in the composition of expenditures are a means of fiscal policy. The implementation of an expanding fiscal policy to combat unemployment means to increase the amount of public expenditure. But at the same time, a composition change, such as increasing subsidies to low-income groups, is also considered an instrument of fiscal policy. Public revenues are monetary values that the state obtains reciprocally or unrecorded with or without the use of cash. Taxes are at the head of public incomes. The fiscal policy tool is not only to change the tax rate or amount, but also to change the distribution of tax types or to introduce new tax types. Public debt can be used as a fiscal policy tool for economic and social purposes, although it appears to be one of the financing ways of the government budget deficits. However, not only the decrease or increase in the amount of the debt, but also the determination of the debt and / or the source of the debt is a means of fiscal policy. A number of fiscal policy objectives can be achieved by giving surplus or deficit in the public budget. The deficit refers to the expanding fiscal policy as it means that the expenditures are overdue. The surplus on the contrary means the inflationist fiscal policy. The discussions of the state's intervention in the economy are based on ancient times. The fiscal policy instruments that the state implements for intervention are ineffective according to some views, and in some cases they are ineffective.

Today, as globalization and capital movements are increasingly liberalized, it is difficult to try to establish both internal balance and foreign trade and debt balance. It has become inevitable for a monetary policy, which is also aimed at price stability, to apply a nominal peg to achieve success. At the end of the twentieth century various targets were tried as monetary policy options. In the first stage, narrow and broad money supply targets are presented. Fixed and floating exchange rate targeting was then proposed. All of them have seen advantages or failures over time. In recent years, open or implicit inflation targeting has been implemented by many countries. It has emerged that inflation targeting does not conform to every economic conjuncture. On the other hand, nominal GDP targeting is proposed and discussed. Another issue to be addressed is whether the levels of variables or change rates are targeted. It suggests that the level determination is more effective in terms of stability (Svenson, 1996; Mankiw and Hall, 1994). The disadvantage of specifying such a target is that it causes cyclical movements in demand conditions. Monetary targeting strategy has three important elements. These are based on the knowledge that monetary aggregates emerge in the management of monetary policy, the pre-declaration of monetary aggregate targets, and the operation of accountability mechanisms to prevent massive and systematic deviations from monetary targets (Mishkin, 2000). Monetary targeting has some advantageous aspects. The first of these is that the Central Bank has the power to apply an indefinite monetary policy taking into account domestic conditions. Secondly, monetary aggregate data can be easily accessed and tracked easily. It facilitates the determination of the level of attainment of these goals. It also has the advantage of reducing the problem of time inconsistency by providing transparency and accountability. However, benefiting from these advantages depends on whether the relationship between inflation or nominal income and the targeted monetary aggregates is strong and stable. However, new financial instruments arising from the financial institutions that emerged after the 1980s have led to an increase in money deposits. Thus, the demand for money and instability of the rate of circulation increased compared to the past. This led to a weakening of the short-run correlation between monetary aggregates and inflation. In the event of this unreliable weak relationship, the monetary magnitudes signal to the market and the transparency and accountability of the Central Bank are also at stake. Monetary targeting is the targeting of a large number of variables that fail. Failure to meet these expectations results in a loss of credibility. In successful cases, both 
monetary aggregates and inflation have been targeted together. In selecting the monetary size, the consistency of the variable with the controllability and the nominal GDP is taken into account. In determining monetary growth targets, the expected rate of circulation trends taking into account potential production and the Quantitative Theory equation, which determines the numerical inflation target policy (Bernanke and Mishkin, 1997:106), have been used. The six monetary targets in Germany can be said to be a Taylor-type rule rather than a Friedman type target (Clarida and Gertler, 1997: 401). Secondly, monetary targeting should be a very flexible application from a rigid rule. In addition to other objectives including production and exchange rate, long term struggle with inflation was targeted.

Fixed exchange rate targeting policies exemplify full dollarization. The semi-fixed exchange rate targeting can be implemented as binding the country currency to a currency basket. Alternatively, a crawling peg may be applied around a symmetrical or asymmetric band. This policy works well in the prerequisite of sufficient foreign exchange reserves of the country. In open economies, there is a close correlation between price level and exchange rate, which supplies a contracting variable. This approach is advantageous when there is no reliable money management understructure. In addition, since the exchange rate was a peg, the exchange rate risk was reduced. Therefore, the nominal interest rate in the country will decrease through the interest rate parity. As a result, inflation expectations will be broken in countries with high domestic debt burden. By means of the purchasing power parity, prices of goods subject to external trade will also decrease. Besides to these short-term effects, governments gain time for the disinflation policy. In the long term, it will cause the recession. However, when monetary magnitudes were targeted, there would first a recession and then growth is taking place. If inflation occurs above the devaluation rate, the country's currency will have overvalued and results in deterioration in the current account balance. It paves the way for financial crises, which are caused by the fall of credit volume due of economic actors' intention to borrow in foreign currency. Since the intervention force of the Central Bank falls, interest rates overreact to foreign capital movements.

The nominal GDP targeting policy has first and foremost political consequences when the target is low or high. Secondly, inflation and other variables can be measured more accurately at shorter intervals. Public understanding of the nominal and real world will also be problematic in terms of public communication. This policy is subject to criticism that creates instability in production and employment, as it does not allow as flexible implementation as others (Ball, 2000; Svensson, 1997). In the price-level targeting policy, systematic responses are given to keep the target in place when there are deviations from the set level. For this purpose, inflationary or deflationary policies are introduced quickly. For this reason, the inflation rate and the variability in production increase.

\section{THE SIMPLE THEORETICAL FISCAL AND MONETARY MODEL}

The Leeper (1991, 1993) model was employed to determine the exogenous and endogenous variables. The model was assumed as a neoclassical macro model. The money was presented in the utility function. The supply side modelled by the Lucas curve. It also includes the tax rule (Perez and Hiebert, 2002).

The model implies a simple form of national income identity given by equation (1).

$$
y_{t}=c_{t}+g_{t}
$$

The total demand consisted of the private consumption $\left(c_{\mathrm{t}}\right)$ and public spending $\left(g_{\mathrm{t}}\right)$, which summarizes the investment and external sector.

$$
y_{t}=\lambda_{0}\left(1-\lambda_{2}\right)+\lambda_{1}\left(\pi_{t}-E_{t-1}\left(\pi_{t}\right)\right)+\lambda_{2} y_{t-1}+\epsilon_{t}
$$


The Equation (2) is the aggregate supply function. The production $\left(y_{t}\right)$ assumed to affected by the inflation $\left(\pi_{t}\right)$ and its past expectations. The production is persisting as the percent level $\lambda_{2}$ of past production.

$$
m_{t}^{d}=\delta_{0}+\delta_{1} R_{t}+\delta_{2} c_{t}
$$

The demand for real money $\left(m_{\mathrm{t}}^{\mathrm{d}}\right)$ depends on interest rate $\left(R_{\mathrm{t}}\right)$ and consumption $\left(c_{\mathrm{t}}\right)$. Both variable coefficients in Equation (3) are positive real values. The money demand partitioned as the private consumption and investment requirements. The demand for government debt was written in Equation (4).

$$
\frac{U^{\prime}\left(c_{t}\right)}{P_{t}}=\beta R_{t} E_{t}\left(\frac{U^{\prime}\left(c_{t+1}\right)}{P_{t+1}}\right)
$$

The utility function of the public was derived as the logarithm of the private consumption $u_{\mathrm{t}}\left(c_{\mathrm{t}}\right)=\log \left(c_{\mathrm{t}}\right)$. The discount factor $\beta \in(0,1)$ was used to explain the steady state real interest rate $1 / \beta$ with no growth. $P_{t}$ is the price level at time t. So, the change at the utility depends on the future expectations of the consumption ability.

$$
R_{t}=\alpha_{0}+\alpha_{1} \pi_{t}+\alpha_{2} y_{t}
$$

The inflation rate $\pi_{t}=P_{t} / P_{t-1}$ and the equation describes the monetary policy rule, that the authority has to adjust the money supply to change the interest rate and responsively the inflation rate. This model also consisted the cyclical behaviour of output where $\alpha_{2}>0$. The government budget constraint in Equation (6) describes government revenues at right-hand side. These are real debts, inflation corrected increase in money supply and tax collection. The expenditures are the government spending and inflation corrected debt services from the previous year.

$$
b_{t}+m_{t}-m_{t-1} \frac{1}{\pi_{t}}+\tau_{t}=g_{t}+\frac{R_{t-1} b_{t-1}}{\pi_{t}}
$$

The real debt $\pi_{t}=B_{t} / P_{t}$ was calculated by the division of the nominal debt by the price level coefficient. Many macroeconomic models describe the tax revenues as the income taxes, taxes on goods and services etc. However the model aggregates the tax revenues $\tau_{t}$. The tax system of the economy was described in Equation (7) where it combines some fixed level of revenue and income tax collected with a proportional tax rate $\left(\tau^{y}\right)$ on income. Furthermore, the government should collect a lump-sum taxes $\left(\tau_{\mathrm{t}}^{\text {rule }}\right)$ to stabilise the dept.

$$
\tau_{t}=\tau_{0}+\tau^{y} y_{t}+\tau_{t}^{r u l e}
$$

The equations (5) to (7) are the monetary and fiscal action policies. The random economic environment was formed in two exogenous behaviours. These are the aggregate supply in Equation (2) and government spending in Equation (8).

$$
g_{t}=\left(1-\rho_{g}\right) g+\rho_{g} g_{t-1}+u_{g t}
$$

The mean government spending $(\mathrm{g})$ presents the customary routine behaviour of the government. The both stochastic models were assumed to track a first-order autoregressive structure. The written equations except these two models had deterministic nature. The whole model would have a steady-state solution when the residual mean set to zero. Than the variables $\mathrm{y}, \mathrm{c}, \mathrm{m}, \mathrm{b}, \mathrm{R}, \tau$ and $\pi$ had a particular solution depending on the constant and variable coefficients in the model. In this case the multi equation model let to be solved for equilibrium values after linearization of the system. However, the models would have solved for purpose of behaviour estimation. When the dependent variable depends on its past realizations, then the dynamic panel data models used for estimation. This model has the 
problem of endogeneity because of the dynamic structure. Anderson and Hsiao (1982) proposed to use second differences and second lagged values of the dependent variable for the controlling of the endogeneity arisen from the correlation between $\Delta y_{t-1}$ and $\Delta u_{t}$. The available instrument amount exceeds the unknown parameter number, when there are three or more time periods (Holtz-Eakin et al., 1988). Arellano and Bond (1991) obtained GMM (Generalized Method of Moments) estimators (Hansen, 1982). They used the moment conditions generated by lagged levels of the dependent variable with the differenced random residuals, which was called "difference GMM estimators".

\section{EMPIRICAL MODEL AND THREE STAGE LEAST SQUARES ESTIMATION}

The data consisted of 2006-2017 quarterly main macroeconomic indicators of Turkey collected from TUIKK and Turkish Central Bank data set. The data set includes 44 observations of quarterly inflation $(\mathrm{P})$, monetary policy rate $(\mathrm{R})$, GDP growth $(\mathrm{Y})$ with nominal prices, broad money $(\mathrm{M})$, government spending $(\mathrm{G})$, tax revenues $(\mathrm{T})$, external debt stock (B) and consumption expenditures (C) for the estimation process. Lending Rate is the average of end-of-period minimum and maximum rates charged by commercial banks on short-term loans to private nonfinancial enterprises; which was central bank policy rate percent per annum for Turkey. Broad money (IFS line 35L.ZK) is the sum of currency outside banks; demand deposits other than those of the central government; the time, savings, and foreign currency deposits of resident sectors other than the central government; bank and traveller's checks; and other securities such as certificates of deposit and commercial paper. General government final consumption expenditure (formerly general government consumption) includes all government current expenditures for purchases of goods and services (including compensation of employees). It also includes most expenditures on national defence and security, but excludes government military expenditures that are part of government capital formation. Tax revenue refers to compulsory transfers to the central government for public purposes. Certain compulsory transfers such as fines, penalties, and most social security contributions are excluded. Refunds and corrections of erroneously collected tax revenue are treated as negative revenue.

All the variables except the monetary rate have been calculated as quarterly percentage change to avoid the unit root. The dependent variable was selected as the quarterly growth instead of Gross Domestic Production because of the same reason. In this case, there are two options to estimate behavioural policy models. One of them is to solve the simultaneous equation system by creating a reduced form. In this case, much of the information contained in the equations will be lost. The alternative is to estimate the equations in the system given below separately. These are stochastic behavioural models of the Equations (2-8) sequentially. Equation (4) includes the both economic contexts either the consumption or the price inflation. The estimated coefficients would differ from the policy model; however, a similar notation was used. The identity equation will not valid anymore due of the estimation modifications and best fit.

$$
\begin{aligned}
& Y_{t}=\lambda+\lambda_{1} C_{t-1}+\lambda_{2} Y_{t-1}+\varepsilon_{1 t} \\
& M_{t}=\delta_{1} P_{t}+\delta_{2} B_{t-1}+\varepsilon_{2 t} \\
& C_{t}=\beta_{0}+\beta_{1} C_{t-1}+\beta_{2} Y_{t-1}+\beta_{3} G_{t-1}+\varepsilon_{3 t} \\
& R_{t}=\alpha_{0}+\alpha_{1} R_{t-1}+\alpha_{2} G_{t}+\varepsilon_{4 t} \\
& B_{t}=\zeta_{1} B_{t-1}+\zeta_{2} P_{t-1}+\varepsilon_{5 t}
\end{aligned}
$$




$$
\begin{aligned}
& T_{t}=\tau_{0}+\tau_{1} C_{t}+\tau_{2} G_{t}+\varepsilon_{6 t} \\
& g_{t}=\rho_{0}+\rho_{1} Y_{t}+\rho_{2} P_{t-1}+\rho_{3} C_{t-1}+\varepsilon_{7 t} \\
& P_{t}=\pi_{1} G_{t}+\pi_{2} P_{t-1}+\varepsilon_{8 t}
\end{aligned}
$$

The variables $Y_{t}, M_{t}, C_{t}, R_{t}, B_{t}, T_{t}, G_{t}, P_{t}$ are endogenous and $M_{t-1}, P_{t-1}, Y_{t-1}$, $C_{t-1}, B_{t-1}, T_{t-1}, G_{t-1}, R_{t-1}$ are exogenous variables in the system.

Autoregressive errors were expected as a priori reason in an economic environment by regression analysis. These type of models have been estimated through dynamic regression with non-linear common factor restrictions and uncorrelated disturbances (Sargan, 1980). The fundamental condition was the strict exogeneity of some of the explanatory variables for the identification in equation systems. Several econometric problems may arise from estimating an economic model equation with lagged dependent variable as explanatory variable, and when the causality flow runs in both direction, so they are assumed as endogenous. In this case, the regressors might correlated with residuals.

If the predictors obtained are biased and inconsistent, it is called the simultaneity bias. Once the structural model has been established, it is necessary to examine each of the equations in the model for the identification. If a single numerical estimation can be obtained for the structural equation coefficients, it is called full identification, and it is over identified when more estimations are possible for a parameter. It is not possible to estimate all of the parameters using any method in case of incomplete identification. The rank assumption was investigated for the determination of the identification by using the structural equations. The test first depends on the comparison of $\left(n_{x}-n_{q}\right)$ versus $\left(n_{z}-1\right)$, where $n_{x}$ is the total number of variables in the system, $\mathrm{n}_{\mathrm{z}}$ is the number of total endogenous variables and $\mathrm{n}_{\mathrm{q}}$ is the number of variables in the mentioned equation. As $\left(\mathrm{n}_{\mathrm{x}}-\mathrm{n}_{\mathrm{q}}\right)>\left(\mathrm{n}_{\mathrm{z}}-1\right)$, all of the equations are over identified, so efficient and unbiased parameter estimations are possible. The parameter matrix of the system has been represented below. That has been used for the investigation of the rank condition.

Table 1. Parameter Matrix of the System

\begin{tabular}{|c|c|c|c|c|c|c|c|c|c|c|c|c|c|c|c|c|}
\hline $\mathrm{q}$ & $Y_{t}$ & $C_{t}$ & $B_{t}$ & $M_{t}$ & $G_{t}$ & $T_{t}$ & $R_{t}$ & $P_{t}$ & $P_{t-1}$ & $Y_{t-1}$ & $M_{t-1}$ & $B_{t-1}$ & $C_{t-1}$ & $G_{t-1}$ & $T_{t-1}$ & $R_{t-1}$ \\
\hline 1 & & 0 & 0 & & & & & 0 & 0 & $-\lambda_{2}$ & & & $-\lambda_{1}$ & & & \\
\hline 2 & & & & & & & 0 & $-\delta_{1}$ & 0 & & & $-\delta_{2}$ & & & & \\
\hline 3 & & & & & & 0 & & & & $-\beta_{2}$ & & & $-\beta_{1}$ & $-\beta_{3}$ & & \\
\hline 4 & & & & & $-\alpha_{2}$ & & & & & & & & & & & $-\alpha_{1}$ \\
\hline 5 & & & & & & & & & $-\zeta_{2}$ & & & $-\zeta_{1}$ & & & 0 & 0 \\
\hline 6 & & $-\tau_{1}$ & 0 & $-\tau_{2}$ & & & & & & & & & & \\
\hline 7 & $-\rho_{1}$ & & & & & & & & $-\rho_{2}$ & & & & $-\rho_{3}$ & & & \\
\hline 8 & & & & & & & & & & & & & & & & \\
\hline
\end{tabular}


The system has been identified, as one of the $\left(\mathrm{n}_{\mathrm{z}}-1\right)=8$ square matrices had a non-zero determinant, which is $D e t \neq 0$ for the first $8 \times 8$ square matrix part of the coefficients.

Fortunately, Hausman (1978) and Wu (1973) developed the test that the independent variables are uncorrelated with the disturbances, under the alternative hypothesis that the instrumental variables estimation is consistent. There would be simultaneity if the endogenous variables are correlated with the disturbances under the alternative hypothesis. Each equation has been estimated with the residuals and their predictions of the variable, which has the same time point with the dependent variable. Furthermore, similar Hausman test has been applied with just its predicted value for the endogeneity, where the estimated model does not contain the constant parameter. The first equation has been excluded because it represents the simple growth model.

Table 2. Hausman Simultaneity and Endogeneity Test Results

\begin{tabular}{|l|l|l|l|l|l|}
\hline \multirow{2}{*}{ Equation } & \multirow{2}{*}{ Variables } & \multicolumn{3}{|l|}{ Hausman Simultaneity } & \multicolumn{2}{l|}{ Hausman Endogeneity } \\
\cline { 3 - 6 } & & Statistic & Prob. & Statistic & Prob. \\
\hline 12 & $\mathrm{M} ; \mathrm{P}$ & $\mathrm{t}=-0.66$ & 0.512 & $\mathrm{t}=-1.45$ & 0.157 \\
\hline 14 & $\mathrm{R} ; \mathrm{G}$ & $\mathrm{t}=2.11$ & 0.042 & $\mathrm{t}=-0.63$ & 0.530 \\
\hline 16 & $\mathrm{~T} ; \mathrm{C}$ & $\mathrm{t}=3.48$ & 0.026 & $\mathrm{t}=0.56$ & 0.643 \\
\hline 17 & $\mathrm{G} ; \mathrm{Y}$ & $\mathrm{t}=1.60$ & 0.117 & $\mathrm{t}=-0.02$ & 0.982 \\
\hline 18 & $\mathrm{P} ; \mathrm{G}$ & $\mathrm{t}=2.98$ & 0.030 & $\mathrm{t}=0.27$ & 0.863 \\
\hline
\end{tabular}

There is simultaneity among policy rate, price inflation and taxes according to the results at the $5 \%$ of significance level. However, the simultaneous or lagged causality has to be valid due to the economic theory. However, the explanatory variables are endogenous for the other equations in the system at the same quarter. That should be interpreted as dynamic causality, or the aggregate economic model is highly dependent on government spending and price inflation.

Three-stage least squares estimates a system of structural equations, where some equations contain endogenous variables among the explanatory variables (Zellner and Theil, 1962). The endogenous explanatory variables are dependent ones from other equations in the system. All dependent variables are explicitly taken to be endogenous to the system and are treated as correlated with the disturbances in the system's equations, which was violating the assumptions of ordinary least squares estimation.

Table 3 Three Stage Least Squares Model Summary

\begin{tabular}{|c|c|c|c|c|}
\hline Equation & RMSE & $\mathrm{R}^{2}$ & $\chi 2$ & prob. \\
\hline $\mathrm{Y}$ & 7.3684 & 0.4999 & 45.15 & 0.0000 \\
\hline $\mathrm{M}$ & 2.9623 & 0.5731 & 92.46 & 0.0000 \\
\hline $\mathrm{C}$ & 5.0376 & 0.8377 & 236.41 & 0.0000 \\
\hline $\mathrm{R}$ & 1.5602 & 0.8961 & 720.86 & 0.0000 \\
\hline $\mathrm{B}$ & 2.8019 & 0.3813 & 27.23 & 0.0262 \\
\hline $\mathrm{T}$ & 17.1827 & 0.4494 & 21.79 & 0.0000 \\
\hline $\mathrm{G}$ & 0.9214 & 0.5087 & 23.04 & 0.0000 \\
\hline $\mathrm{P}$ & 1.1104 & 0.7904 & 155.79 & 0.0000 \\
\hline
\end{tabular}

The estimated equations are significant at 5 percent. The parameter estimations have been given in the system equations. 


$$
\begin{aligned}
& \widehat{Y}_{t}=5.1040-0.6498 C_{t-1}+0.3073 Y_{t-1} \\
& \widehat{M}_{t}=1.6704 P_{t}+0.2875 B_{t-1} \\
& \hat{C}_{t}=11.5343-0.8679 C_{t-1}-2.6809 G_{t-1}+0.4460 Y_{t-1} \\
& \hat{R}_{t}=2.2672-0.9397 G_{t}+0.9378 R_{t-1} \\
& \hat{B}_{t}=0.3901 B_{t-1}-0.4755 P_{t-1} \\
& \widehat{T}_{t}=-14.3709+0.6498 C_{t}+8.3059 G_{t} \\
& \widehat{G}_{t}=3.3738-0.0738 Y_{t}-0.4301 P_{t-1}-0.0474 C_{t-1} \\
& \hat{P}_{t}=0.8318 G_{t}+0.1712 P_{t-1}
\end{aligned}
$$

The parameter estimations are significant in the system (see Appendix). The real income is a positive function of past income and negatively affected by the private consumption, which is estimated due from imported goods and services, also external transfer of income. The money supply was adjusted for coping with the inflation level and debt services. Past consumption forces the households to spend their future earnings that will cause to reduce the private consumption. Government spending is also reducing the private consumption, as of inflation tax, caused by inefficient and unreal growth. The policymakers increase the monetary rate as much to compensate the government spending. The external debt services have been highly paid by the inflation effect by issued money supply. The tax revenues have been meet as a great portion from the income created by the government spending. That means government is still the main leader of the economy in Turkey. The government spending assumed financed by the price level increase due of inefficient investments. Turkish government pursued past ten years an inflationist fiscal and monetary policy for the growth.

Figure 1. Quarterly GDP Growth and Price Inflation Rate Predictions

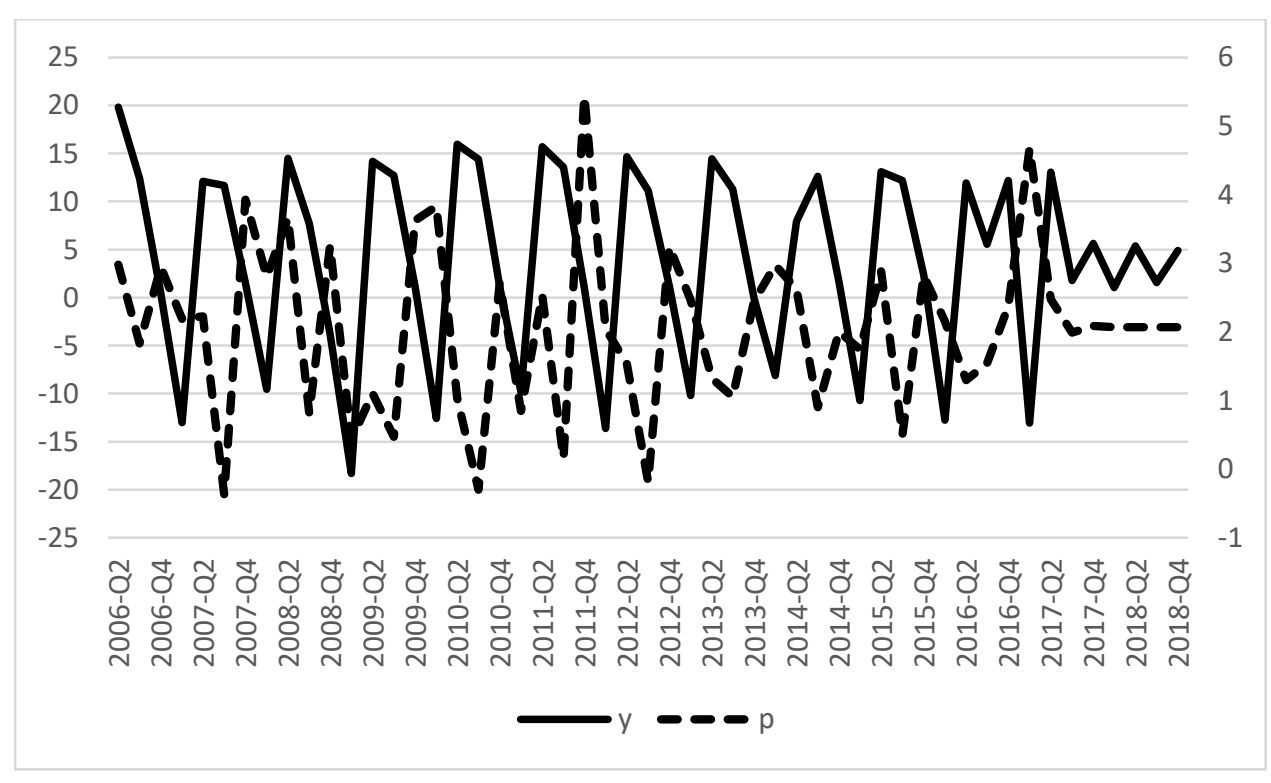

The quarterly growth was expected about 1.03-5.38\% during the year 2018 whilst the inflation rate became about $2.07 \%$. The predictions are seasonal smoothed values. 
Table 4. Year 2018 Variable Predictions

\begin{tabular}{|c|c|c|c|c|c|c|c|c|}
\hline Quarter & $\mathrm{Y}$ & $\mathrm{P}$ & $\mathrm{M}$ & $\mathrm{R}$ & $\mathrm{C}$ & $\mathrm{G}$ & $\mathrm{B}$ & $\mathrm{T}$ \\
\hline 2018-Q1 & 1,033 & 2,068 & 4,074 & 7,033 & 0,548 & 2,057 & 1,832 & 3,071 \\
\hline 2018-Q2 & 5,383 & 2,068 & 3,981 & 6,926 & 6,466 & 2,061 & 1,698 & 6,947 \\
\hline 2018-Q3 & 1,538 & 2,071 & 3,948 & 6,823 & 1,320 & 2,064 & 1,646 & 3,631 \\
\hline 2018-Q4 & 4,883 & 2,068 & 3,928 & 6,731 & 5,779 & 2,060 & 1,627 & 6,493 \\
\hline
\end{tabular}

The dynamic predictions of the related variables for the four quarters of year 2018 have been presented in Table 4. The growth trend will tend to decrease compared to past years' performances. Government is unable to control the growth just by managing the central spending about $\pm 10 \%$ change to previous quarter at the period $2017 \mathrm{Q} 3$, either on private consumption and external debt services. The growth was predicted about $1.03 \%$, consumption increased $0,55 \%$ and external debt services had to grow $1.83 \%$. The government had to spend at least with $2 \%$ increase and quarterly inflation ratio remained $0.36 \%$ with any change of government spending. It tends to increase linearly from $-8 \%$ to $8.7 \%$ for the same interval of spending.

Figure 2. Money Supply, Monetary Rate and Tax Revenue Change according to Government Spending

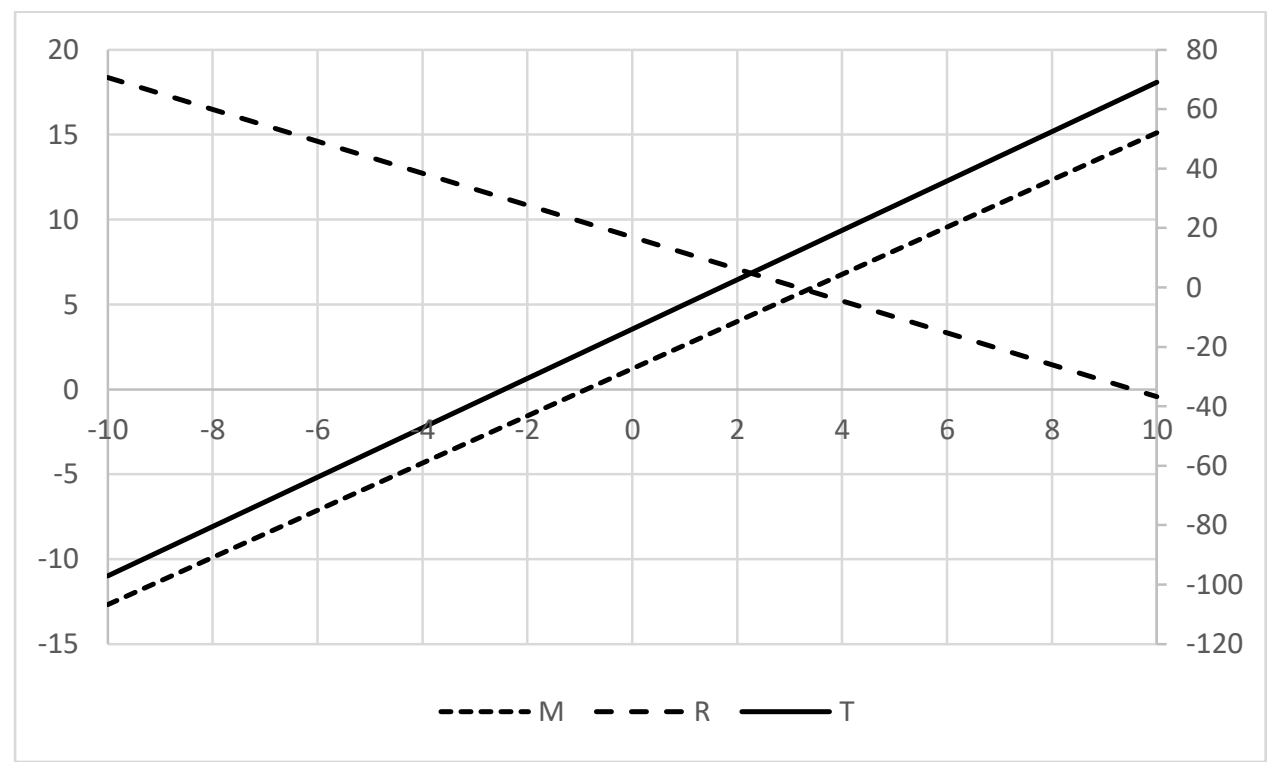

The main effect of the government spending fiscal policy is on the money supply, interest rate and moreover on the tax revenues. For $10 \%$ decrease in spending tax revenues drop a similar percent, but for $10 \%$ increase, it gains approximately $70 \%$ increase in tax collection, as the real income remains as the mentioned level, so the government financed its expenditures by the inflation.

\section{OPTIMIZATION}

A general optimization model is defined as below. $\mathrm{f}(\mathrm{x})$ is a hypersurface target function and defined in $(\mathrm{m}+1)$ dimensional Euclidian space subject to $\mathrm{g}(\mathrm{x})$ hypersurface restrictions.

$[$ Min or $\operatorname{Max}] f(x), x \in E^{n}$ 
Subject to $g_{i}(x)[\leq,=, \geq] b_{i} ; i=1,2, \ldots, m$

Where $x \geq 0$

Newton-Rapson and its derivatives are mostly used optimization techniques, which be subject to the gradient vector and Hessian matrix. Gradient Vector is a column or row vector containing first-order partial derivatives of a given multivariate continuous and differentiable function. Hessian Matrix is a square matrix of size (nxn) that is symmetric with respect to the original diagonal, containing partial derivatives of the second order of the multivariable function given (Faigle et.al, 2002: pp.16-19).

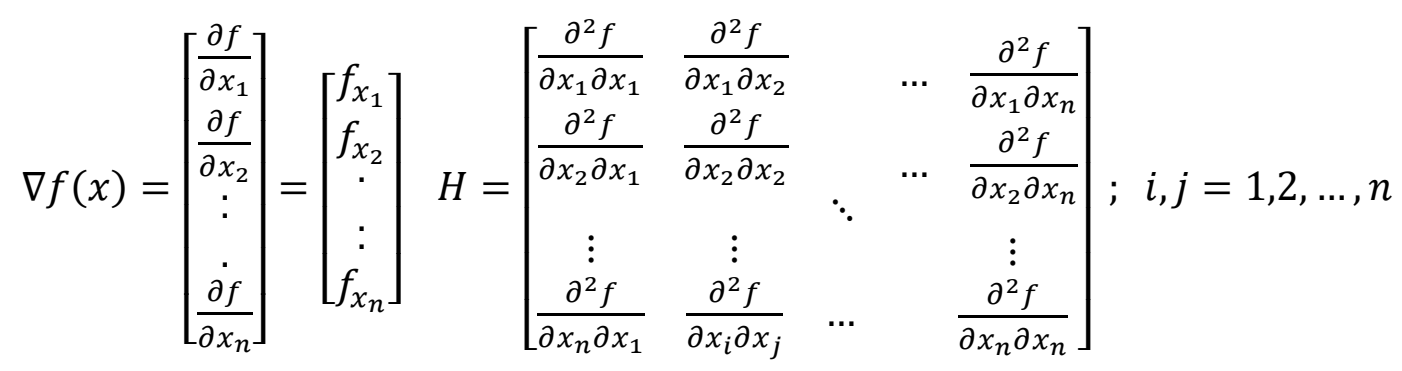

The condition for an unconstrained optimization problem is; the Gradient Vector of the function $\mathrm{f}(\mathrm{x})$ is equal to zero $\nabla f(x)=0$ (Bazaara et.al, 2006: p.167). The main purpose of the Lagrange multipliers method is to solve the constrained problem by reducing it to an unconstrained problem for solving the problem through the dynamics of the unrestricted multivariable nonlinear optimization problem. In this context, since the constraints are in the form of equations, the objective function is added by means of corresponding Lagrange multipliers in each section. Since each constraint equals zero, the Lagrange function and the objective function are basically identical. The requirement to use the Lagrange multipliers method is the same as the conditional principle in the mentioned classical optimization problem.

$\mathcal{L}\left(x_{1}, x_{2}, \ldots, x_{n}, \lambda_{1}, \lambda_{2}, \ldots, \lambda_{m}\right)=f(x)-\left[\lambda_{1} g_{1}(x)+\lambda_{2} g_{2}(x)+\cdots+\lambda_{m} g_{m}(x)\right]$

where $\lambda_{i}(i=1,2, \ldots, m)$ are called the Lagrange multipliers. The nonlinear problem becomes as in Equations (28) and (29) with the decision variables $x_{k} ; k=1,2, \ldots, n$.

$$
\begin{aligned}
& \frac{\partial \mathcal{L}}{\partial x_{k}}=0 \quad ; k=1,2, \ldots, n \\
& \frac{\partial \mathcal{L}}{\partial \lambda_{i}}=0 \quad ; i=1,2, \ldots, m
\end{aligned}
$$

The linear and lagged structure does not allow to optimize the growth model for all the policy tools. Therefore, the following equations have been written using the equations 19-26 to calculate the marginal effects of tax revenues and government spending. The monetary tools have not been achieved in the growth equation.

$$
\begin{aligned}
& \hat{Y}_{t}=-7.49498+0.56396 C_{t-1}+0.01748 Y_{t-1}+1.74204 G_{t-1} \\
& \hat{Y}_{t}=14.6209+0.01748 Y_{t-1}+0.867896 T_{t}-7.25475 G_{t}
\end{aligned}
$$

Derivatives are taken according to the equilibrium fiscal policy instruments.

$$
\frac{\partial \hat{Y}_{t}}{\partial T_{t}}=0.86786, \quad \frac{\partial \hat{Y}_{t}}{\partial G_{t}}=-7.25475
$$


Tax revenues yielded a $14 \%$ less income return than its scale. However, the government spending has a negative impact on real income, it declining approximately $7.25 \%$ for each $1 \%$ increase in government spending for the observed levels of economic indicators.

\section{DISCUSSION}

Developed countries use monetary and fiscal policy tools to manage economic and social life, and to protect against international competition. These are mainly money supply, policy interest, government spending and tax rates. These tools operate according to Keynesian theorem in the full market economy. However, in Turkey populist planning was used for many years. Economically protected or externally dependent policies have been implemented. It is seen that the preliminaries of the market economy do not developed now, as the academic researches do not fit the economic theory in Turkey as much. These essentials are presumably entrepreneurship, a technology infrastructure linked to education, and culture that has not made the habit of commitment to the state.

In this case, the most basic progressive monetary instruments, interest rate and money supply, were ineffective in the short term for economic intervention. The state follows a growth policy based entirely on central expenditure. Economic planning based on econometric models is therefore unlikely under these circumstances. 


\section{REFERENCES}

ANDERSON, T.W., C. HSIAO (1982). "Formulation and estimation of dynamic models using panel data", Journal of Econometrics, 18, 47-82.

ARELLANO, M., S. BOND (1991). "Some Tests of Specification for Panel Data: Monte Carlo Evidence and an Application to Employment Equations", The Review of Economic Studies, 58 (2), 277-297.

BALL, L. (2000). "Policy Rules and External Shocks", NBER Working Papers, 7910.

CLARIDA, R. ve M. GERTLER (1997). "How the Bundesbank Conducts Monetary Policy?", Reducing Inflation, Motivation and Strategy, The University of Chicago Press, 363413.

FAIGLE, U., KERN, W., STILL, G., 'Algorithmic Principles of Mathematical Programming', Springer Science, 2002, Dordrecht

HANSEN, L. (1982). "Large sample properties of generalized method of moments estimation”, Econometrica, 50 (3), 1029-1054.

HOLTZ-EAKIN, D., W. NEWEY, H.S. ROSEN (1988). "Estimating Vector Autoregressions with Panel data", Econometrica, 56 (6), 1371-1395.

LEEPER, E. M. (1991). "Equilibria under 'active' and 'passive' monetary and fiscal policies”, Journal of Monetary Economics 27 (November 1991), 129-47.

LEEPER, E. M. (1993). "The policy tango: Toward a holistic view of monetary and fiscal effects", Federal Reserve Bank of Atlanta Economic Review, 18 (4), 1-27.

MISHKIN, F.S. (2000). "From Monetary Targeting to Inflation Targeting: Lessons from the Industrialized Countries", NBER Working Papers.

PEREZ, J.J., P. HIEBERT (2002). "Identifying Endogenous Fiscal Policy Rules for Macroeconomic Models", European Central Bank Working Paper No. 156.

SARGAN, J.D. (1980). "Some Tests of Dynamic Specification for a Single Equation", Econometrica, 48, 879-897.

SVENSSON, L.E.O. (1997). "Optimal Inflation Target, Conservative Central Banks and Linear Inflation Contracts”, American Economic Review, 87 (1), 97-114.

ZELLNER, A., H. Theil (1962). "Three stage least squares: Simultaneous estimate of simultaneous equations", Econometrica, 29, 54-78. 
ÇILINGIRTÜRK et al. / Optimization of Turkish Macro Econometric Fiscal and Monetary Policies for Growth

\section{Appendix}

Three Stage Least Square Estimates

\begin{tabular}{|c|c|c|c|c|c|c|}
\hline & Coef. & Std. Err. & $z$ & $P>|z|$ & [95\% Conf. & Interva1] \\
\hline \multicolumn{7}{|l|}{ y } \\
\hline${ }_{\mathrm{L} 1 .}^{\mathrm{C}}$ & -.6498286 & .0985213 & -6.60 & 0.000 & -.8429268 & -.4567303 \\
\hline $\mathrm{L1}^{\mathrm{y}}$ & .3072684 & .117053 & 2.63 & 0.009 & .0778489 & .536688 \\
\hline _cons & 5.104043 & 1.174796 & 4.34 & 0.000 & 2.801485 & 7.406602 \\
\hline \multicolumn{7}{|l|}{ m } \\
\hline L1. & .2875083 & .1006081 & 2.86 & 0.004 & .09032 & .4846966 \\
\hline $\mathrm{p}$ & 1.670365 & .223605 & 7.47 & 0.000 & 1.232107 & 2.108622 \\
\hline \multicolumn{7}{|l|}{ C } \\
\hline${ }_{\mathrm{L} 1 .}^{\mathrm{C}}$ & -.8678998 & .082578 & -10.51 & 0.000 & -1.02975 & -.7060499 \\
\hline $\begin{aligned} \mathrm{y} \\
\mathrm{L} 1 .\end{aligned}$ & .4460024 & .094941 & 4.70 & 0.000 & .2599214 & .6320835 \\
\hline L1. & -2.680926 & .6527569 & -4.11 & 0.000 & -3.960306 & -1.401546 \\
\hline _cons & 11.53428 & 1.570649 & 7.34 & 0.000 & 8.455869 & 14.6127 \\
\hline \multicolumn{7}{|l|}{$r$} \\
\hline L1. & .9378285 & .0349659 & 26.82 & 0.000 & .8692966 & 1.00636 \\
\hline $\begin{array}{r}\mathrm{g} \\
\text { _cons }\end{array}$ & $\begin{array}{r}-.93974666 \\
2.267193\end{array}$ & $\begin{array}{l}.2851238 \\
.6626524\end{array}$ & $\begin{array}{r}-3.30 \\
3.42\end{array}$ & $\begin{array}{l}0.001 \\
0.001\end{array}$ & $\begin{array}{r}-1.498579 \\
.9684177\end{array}$ & $\begin{array}{r}-.3809143 \\
3.565968\end{array}$ \\
\hline \multicolumn{7}{|l|}{$b$} \\
\hline L1. & .390063 & .129459 & 3.01 & 0.003 & .136328 & .643798 \\
\hline L1. & .4754669 & .1916714 & 2.48 & 0.013 & .0997978 & .851136 \\
\hline $\begin{array}{r}c \\
g \\
\text { _cons }\end{array}$ & $\begin{array}{r}.6497549 \\
8.305888 \\
-14.37085\end{array}$ & $\begin{array}{l}.2614791 \\
4.305974 \\
8.620855\end{array}$ & $\begin{array}{r}2.48 \\
1.93 \\
-1.67\end{array}$ & $\begin{array}{l}0.013 \\
0.054 \\
0.096\end{array}$ & $\begin{array}{r}.1372653 \\
-.133666 \\
-31.26742\end{array}$ & $\begin{array}{l}1.162245 \\
16.74544 \\
2.525714\end{array}$ \\
\hline \multicolumn{5}{|c|}{1301944} & & -.0171637 \\
\hline $\begin{array}{l}\text { C } \\
\text { L1. }\end{array}$ & -.0474026 & .0171934 & -2.76 & 0.006 & -.081101 & -.0137042 \\
\hline L1. & -.430138 & .0994418 & -4.33 & 0.000 & -.6250404 & -.2352356 \\
\hline _cons & 3.373776 & .3301548 & 10.22 & 0.000 & 2.726685 & 4.020868 \\
\hline \multicolumn{7}{|c|}{.6438738} \\
\hline L1. & .1712409 & .080049 & 2.14 & 0.032 & .0143478 & .328134 \\
\hline $\begin{array}{l}\text { Endogenous } \\
\text { Exogenous val }\end{array}$ & $\begin{array}{ll}\text { les: } & \text { y } n \\
\text { es: } & \text { L.c }\end{array}$ & 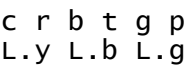 & L. $r$ L.p & & & \\
\hline
\end{tabular}

